\title{
Temenos Special Issue
}

\author{
Connected with God: \\ Body, the social, and the transcendent
}

\author{
MINNA OPAS \\ ANNA HAAPALAINEN \\ University of Turku
}

\begin{abstract}
The special issue Connected with God: Body, the Social, and the Transcendent addresses the very topical question of the architecture of religious, especially Christian, experiences. Specifically, it examines the processes in which Christians experience the connection with, and gain knowledge of, God in and through the body, and, in particular, the role of social relatedness and morality in generating and informing these experiences. The issue challenges the view of an individual subjective relationship with God, and argues that Christian experiences of God's presence are not solely a matter of an individual's relationship with the divine but are very much made possible, guided, and conceptualised through corporeal relationships with social others believers and other fellow-humans. Through detailed ethnographic and historical examination, the issue also addresses the question of whether and how the form of Christianity practised influences people's experiences of divine presence.
\end{abstract}

Keywords: Christianity, Protestantism, senses, body, social

Christianity, especially in its charismatic forms, is growing quickly in the so-called Global South. Charismatic forms of Christianity are also gaining ground in the West within Christianities customarily regarded as less charismatic, such as Lutheranism. People need to feel their connection with God, to experience it as something tangible and affective. It is common among Christian believers to describe their relationship with God in sensory language: it is people's hearts that 'see' God, and God may 'touch' a person, for example. A personal revival of faith and religious experience is often described with corporeal imagery. Encounter with God can be described even viscerally. Believers shiver, feel warmth, see light, hear angelic voices, and feel the presence of the divine; the connection with God permeates the 
body. It is in and through the processes thus described that Christians claim to gain knowledge of God.

But the process of knowing God, to be in relationship with God, is not limited to the relationship between the individual and a transcendent God, but extends into the social space. Other people (as well as objects) participate in the generation of the experiences of God's presence and in assessing the authenticity of the experiences. This raises a question about the relationship between corporeality, epistemology, and the social: how do people gain knowledge of God's presence in Christianities, and, especially, what is the role of the human social sphere in these processes?

By focusing on the social in the experience of God, this special issue seeks to challenge the idea of an individual subjective and intimate relationship with God: how individual, after all, is the person-God relationship? Weberian analysis of Protestantism, the scholarly focus on Charismatic forms of Christianity and, among other things, the commonly held Christian view of the salvation of the individual have directed researchers to study humanGod relationships at the level of the individual's sensory experiences and to attempt to surpass the body-mind division. In this special issue we wish to go beyond the autonomous subject to examine how people's relationships with the divine emerge from a multifaceted socio-bodily dynamic. The issue subscribes to the view of bodies being defined by their capacities to affect and be affected (Blackman 2012), and to this multidirectional affectivity being at the heart of the Christian experiences of God. We are interested in how social interaction, taking place at the interfaces of human bodies (regardless of how these bodies are understood in each specific case), affects the experience or the process of knowing God. What characterises the processes in which bodies, personhoods, and relationships coalesce in forming experiences of divine presence? In short, we wish to explore the coconstitutive processes that give rise to the bodily experiences conceptualised as the presence of God or as media for knowing God, and to find ways to speak about and analyse such experiences. However, we also subsume the new-materialist critique of constructionism and seek to bring to the fore the unconscious and the material that cannot be (verbally) conceptualised in the experiences of God's presence.

Although the human sensory experiences of Christian transcendence have gained much scholarly attention (e.g. Cassaniti \& Luhrmann 2011; Cattoi \& McDaniel 2011; Chidester 2005; Csordas 1993; 2002; Gavrilyuk \& Coakley 2011; Hart \& Wall 2005; Klaver \& van de Kamp 2011; Luhrmann 2004; Orsi 2006; Rudy 2013), there is also a growing field of study concentrat- 
ing on the meaning of the social in relation to experiencing or knowing God. The connection between the body and the social in the context of religion is, of course, not a recent topic but has been examined, for example, from the perspectives of phenomenology (Bourdieu 1990; Merleau-Ponty 1965 [1945]), body's metaphoric reproduction of the social (Douglas 2002 [1966]), techniques of the body (Mauss 1973), and social construction and body's interaction with order and disciplinary systems (Foucault 1975; 1997). In the more recent study of Christianity, several different approaches to the role of the social other in the experiences of Christian divine can be disclosed. The social has been observed to play a role in rehearsing or training bodies and minds to experience God's presence (Bialecki 2011; Bielo 2004; Brahinsky 2012; Coleman 2006; de Witte 2009; 2011). It has been noted, for example, that the ability to connect with God requires the development or adoption of a different theory of the mind, one which departs from the western understanding of the mind as strictly delineated and individual (Luhrmann 2012), and that the sensory perceptions and the knowledge of God depend largely on what e.g. Birgit Meyer $(2008 ;$ 2010) has termed 'sensational forms' - ways of inducing experiences of the transcendent. Other scholars emphasise the different processes of co-constitution in the formation of experiences of the Christian divine. (Bialecki 2015; Csordas 1994; Mitchell 2015; Orsi 2006; see also McGuire 2016.) In this view, the experiences of divine presence emerge as a result of material and physical inter-connectedness between persons, and including Christian divinities. Often, the framework of analysis in these studies has been that of lived religion. In general, then, two main tendencies in these approaches to the body and the social in the context of Christian experiences of the divine - one emphasising practices of 'cultivation' and other those of 'constitution' - can be found, albeit in many of the approaches they overlap.

This special issue builds in various ways on these approaches. Although the focus is in the social, it is the very intimate 'small scale' sociality that we are particularly interested in. Previously, crowds - the group effort - have been seen to play a significant role in generating religious experiences. In Pentecostal and Charismatic Catholic mass gatherings, for example, bodies are rehearsed into experiencing through careful choreographies and planned environments (Brahinsky 2012; de Witte 2009; 2011). In this issue we wish not only to examine crowds but also to open a space for the study of experiences of divine presence within the framework of the more intimate social relationships amidst which Christians live their daily lives. How the social other is part of the experience of God's presence or of the knowledge of God, 
for example, in the context of family relationships, religious study groups, or combat fighting sessions? How does the presence of and relatedness with equal bodies, fellow-believers, affect the experience of the Christian transcendent, and how, if at all, do these experiences differ from or relate to those influenced by social, religious, and moral hierarchies?

In studying the role of human social relations in the processes of knowing God, epistemological and semiotic questions, and the moral problems they entail, play a central role. The means available for Christians to interact with God and to sense the presence of God in their lives and their bodies, and to talk about these experiences, have preoccupied theologians, lay Christians, and researchers alike for centuries. What characterises the Christian sensorium in and through which the connection with God becomes tangible? Can God be reached through the five (or six) senses normally attributed to western people's physical bodies? (On the cultural variability of the human sensorium, see Classen 1993.) Or does such connection require a specifically spiritually tuned sensorium? At least since the time of Origen of Alexandria Christian theologians have often employed the term 'spiritual senses' to denote the human ability to experience God's presence, although the ways of conceptualising such senses have varied (Gavrilyuk \& Coakley 2012). One aim of this special issue is to examine the ways and technologies related to the body in and through which Protestant Christians experience God's presence. However, as interesting as this question is, such an approach easily leads to a mono-directional view of the human-God relationship. God's presence becomes experienced by and material to human beings. The idea of the Christian God as transcendent, omnipotent, and pre-defined finds its blueprint in the social scientific research on religion, in which people are understood to have only limited possibilities to affect gods, deities, and their plans (Espirito Santo \& Tassi 2013, 21). The special issue's emphasis on the role of the social other, however, makes visible the co-constitutive relationship between people and God and other Christian deities. The case studies in this issue show that human beings themselves, especially the social others under examination, affect their experiences of God and, thus, their understandings of God. This is not an ontological stance but an epistemological one, and as such does not aim to nullify the importance many Christians give precisely to God's pre-defined and unchangeable nature. Rather, the observation works to elucidate the dynamism of Christian devotees' lived religion: although God (and even people's life courses) may be held as predefined, everyday life is considerably more complex.

Woven into the texture of Christian experiences of God are questions 
of morality and ethics. The cases show that moral evaluations made both by fellow-human beings and the believer him/herself crucially affect the perceptions of the truthfulness and legitimacy of one's experiences and how they are conceptualised. Whether one is a 'true believer' depends not solely on one's own understandings but on others' evaluations of experiences. Although through religion ethics is often thought to be intellectualised, materialised, and transcendentalised (Lambek 2010, 3), these evaluations are firmly grounded in grassroots daily concerns, and especially in the question of belonging. To be a member of a Christian collectivity, does one need to have experiences of God's presence and, if so, what kind? Foucault denotes ethics as a 'modality of power' that 'permits individuals to effect by their own means or with the help of others, a certain number of operations on their own bodies, souls, thoughts, conduct, and a way of being' (Foucault $1997,225)$. It is a means of transforming oneself into 'a willing subject of a particular discourse' (Mahmood 2014, 224). The idea of 'willing subjects' not only intertwines with language or discourses, but also the senses, mimesis, kinesthetics, audition, and other somatic forms of 'piety'. When these bodily experiences are incorporated in processes of ethical learning, as can be seen in the cases this special issue presents, the human sensorium becomes 'an object of pedagogy and ethical atunement' (Hirschkind 2006, 83f.). This can be called 'moral and ethical embodied pedagogy', especially when related to the experiences of God's presence. It attempts to direct believers through their efforts to evaluate these experiences, but also to communicate their experiences to others. The cases presented in this special issue show that spiritual experiences are resources that give the sense of being part of some larger meaning or script, the feeling of value in one's own life, in the eyes of the community, and before God, and the sense of guidance and 'tools' to comprehend the world. (Utriainen 2016.)

\section{The social other and Protestant experiences of divine presence}

The special issue includes five original articles focusing on different Protestant churches in Europe and South America. In the opening article Gábor Ittzés provides a historical perspective on the topic at hand by examining sixteenth-century Lutheran discussions on the bodily aspects and social embeddedness of knowledge in the eschatological thought of later sixteenthcentury Lutherans. He shows that the Lutheran view of the human being was, much in Luther's spirit, one which was yet to make the later modern distinction between the body and the mind or soul; even disembodied 
souls retained the body's sensory capacities. He also demonstrates that the individual's knowledge in the interim state of the afterlife was thought to be interpersonally constituted and centred on the human community, and especially on the question of human beings recognising each other in the hereafter. Jessica Rivers' article focuses on evangelical fighting ministries in Rio de Janeiro, Brazil. Rivers examines how participants in jiu-jitsu grappling rehearse, and in their connected social interaction seek, both to achieve a personal relationship with God and to demonstrate this relationship to fellow-believers. Bodily and affective interaction with others, especially physical hardship and laughing and crying together, is shown to be constitutive of and constituted by human-divine relations. In her article Minna Opas examines the experiences of connection with God among the indigenous evangelical Yine people of Peruvian Amazonia. For the Yine, dreams are a principal locus for encounter with the divine. Opas advances a view of these encounters as co-acted experiences of the divine, influenced both by Christian non-human others understood as active social agents and fellow-believers through the practice of dream interpretation. In another geographical and denominational context Jamie Barnes also undertakes to forward a view that takes seriously the agency of the Christian God. Based on a phenomenological analysis of interviews of a member of a Christian network and auto-ethnographical materials, he argues that both bodies and worlds are formed in the human experiences of the divine. An important element of these processes is the believers' attempts to express their experiences to themselves and others through metaphorical translation into the more familiar realm of the everyday. In the concluding article Anna Haapalainen examines the experiences of being connected with God within the institutional framework of the Evangelical Lutheran Church of Finland. She shows that the experiences are formed within the tension created by the church workers' attempts to retain the authority to define the right form of divine experiences within the church and lay Christians' striving for a personal and unmediated connection with God. The discussion reveals that the practices concerning the 'spiritual senses' are used in very different ways in different denominations, but also that the profound questions concerning encounter with God share much common ground.

Together the articles in this special issue show that the human body is in multiple ways at the centre of Christian experiences of God and of the divine: the experiences emerge from, are mediated by, and negotiated in relation to the body. One ontological question Christian experiences and knowledge of God poses concerns the nature of the body and its relation to personhood 
and spirit. Ittzés' contribution shows that sixteenth-century Lutheranism, which was still in many ways tied to Medieval thinking, understood the soul and body as inseparable: the 'naked soul' could appropriate the body's epistemic functions in the interim state - it retained the bodily sensorium. Twentieth-century scholarship put forward the view that such understandings had been abandoned at the outset of the modern era. The Protestant tendency for purification (Latour 1993 [1991]; Keane 2007; Weber 2005 [1930]) was especially understood as creating an understanding of the body and $\mathrm{soul} / \mathrm{mind}$ as separate from one another. However, the articles in this special issue contest the modern purified view of the Christian (Protestant) person in many ways. They advance the view that contemporary Christian bodies are not only inseparable from the soul but also qualitatively different from secular bodies and from one another. This production and transformation of Christian bodies often takes place through powerful spiritual experiences, as Barnes and Haapalainen demonstrate in their articles. Spiritual experiences have a transformative effect on the believer's body and the sensorium. But not only on them: as the articles show, this specific Christian body and sensorium - 'infused with and constituted by Spirit' (Barnes this issue) produces different worlds too. This particularity of Christian bodies is also noted by Opas in her article on the Peruvian indigenous Yine evangelicals. For them, faith is materialised as a physical organ that can be felt within a person's body and that grows as their faith strengthens. A faithful body does not therefore come to be in an instant, but its production is an ongoing enterprise. Similarly, Christian bodies can also be 'work-in-progress' in urban contexts, as Rivers demonstrates in her article on Brazilian fighting ministries, which require constant work by their participants to produce proper Christian bodies.

The cases discussed in this issue confirm the often-noted difficulty Christians have in expressing the connection with God through sensory language. Regardless of how the sensorium is conceptualised in each geographical and cultural context, the experience of God appears to be beyond its reach. Even when evidenced by familiar bodily features or actions - as in the case of the Brazilian evangelicals by laughter and crying (Rivers) - God-affected actions are separated from occurences understood as secular. Whether through ontologically different 'speaking bodies' (Barnes) or 'steered bodies' invested with spiritual sensitivities (Haapalainen), bodies made open by physical exhaustion (Rivers), or through a separate organ radiating faith resulting in certainty and confidence in one's body (Opas), people need to attune their sensoria or acquire an additional spiritual sense to feel con- 
nected with, and gain knowledge of, God. However, whereas for some of these Christians the world opened by their Christian sensorium constantly feeds into their bodily existence, thus allowing them to live in a different world, for others the experience is not equally unambiguous and they remain locked in a continuous struggle to distinguish between divine and mundane sensations. Regarding sensoria, the sixteenth-century Lutheran thinkers present an exception among these cases. In their writings the ability to be connected with God is not explicitly raised, as attention is instead directed towards the question of remaining connected with one's family. This implies, as Ittzés notes, that Lutherans did not find a connection with God problematic. It was a given and natural condition of the human being. In general, however, the articles show that the normal human physical sensorium falls short of reaching the divine, which requires that qualitatively different kinds of capability that work on a distinct existential logic. These capabilities, often glossed as the 'spiritual senses', both surpass the human body and remain inseparable from it.

These struggles to conceptualise spiritual experiences of God's presence turn also into difficulties in communicating them to fellow-Christians and the wider public. The solutions vary: one can strive to affect others by writing and thus communicate what is interpreted as the authentic and true substance of faith (Ittzés); create connections with others and invigorate similar emotions in them by laughing or crying (Rivers); transmit one's experience by using metaphors that convey the other-worldliness of the experience (Barnes) or through dream-telling that anchors the experiences to shared cultural knowledge (Opas); or, finally, those who have been-intouch with God can be guided to describe their experiences in a recognisable way and can be given a sound theological explanation to ease their doubt (Haapalainen). Communicating experiences to others for which there is no vocabulary remains problematic, despite the effort.

The core question of this special issue concerns the role of the social other in informing and generating experiences of God's presence. The case studies afford evidence of the centrality of the 'other' for the experience of God. Taken together, they thus contest the deep-seated understanding in scholarship of the individuality of Protestant faith. From early Lutherans to contemporary evangelicals in different parts of the globe, Christians, just as human beings in general, are understood as being not only related to, but also constituted by their relationships with others. Christians' connection with God is not independent of these relationships either. This becomes explicit in the way sixteenth-century Lutherans, instead of problematising 
the human capacity to gain knowledge of God, concentrate on the question of disembodied souls' capacity to gain knowledge of their living kin. Ittzés' analysis suggests that the need to affirm the continuation of social relatedness in the afterlife is proof for Lutherans of the existence of God's kingdom. The case studies raise affectivity as a central means by which the social other participates in people's experiences of divine presence. Rivers shows that experience of God's presence among members of Brazilian fighting ministries is gained through very physical actions: combat fighting, and laughing and crying. God cannot be reached by mere contemplation, but the connection presupposes social and physical interaction between affective bodies. The affectivity of bodies is also central to the Finnish Evangelical Lutheran (Haapalainen) and Amazonian indigenous evangelical (Opas) experiences of the divine. These accounts suggest that affectivity may be seen as bridging the views that emphasise human sociality on the one hand, and divine work on human bodies on the other, in bringing about Christian experiences of being connected with God. The tension between these views is taken up by Barnes, who criticises approaches that reduce (intentionally or unintentionally) Christian experiences of God to socially produced phenomena for eclipsing, ignoring, or denying the agency of God. For him, and for the people he has interviewed, it is God as an active agent who transforms human sensoria and human bodies. But fellow-human beings also participate in the processes of connecting with God through interpretative practices. Opas shows that the Yine evangelicals both instruct one another in how to avoid Satanic traps and take part in the analysis of the significance of dream experiences in relation to their dream encounters with the divine. Through these actions fellow Christians attempt to guard and organise the social and moral life of the evangelical collectivity. Haapalainen observes a similar process taking place among Finnish Evangelical Lutherans. In their attempt to retain control of theological interpretation, ministers assume the role of analysts of lay-Christian experience, and especially of the God-devil axis.

Although not necessarily using the language of morality, the cases in this special issue tackle also with the question of the ethical and moral evaluation of experiences of the divine, which emerges not as a mere mode of control, but as a more refined attitude towards various shared or personal experiences. This may be seen as a problem space in which continuous negotiation about spiritual experiences and their nature is conducted. The articles show that moral evaluations may focus either on the individual or the collectivity, but that in most cases these two sides are inseparably intertwined. Ittzés examines how the process of evaluation is targeted at the community of 
the dead and the living. The deceased souls' concern for the well-being of their living kin is proof of their moral condition and thus their humanity, making them eligible for salvation. In the case of the fighting ministries, Rivers suggests that moral evaluation is linked to respect for one's opponent and seeking perfection in training. It is a tightrope walk: honouring the opponent is perfected in practice as well as in not hurting the opponent. Slacking in practice or in a fight would disrespect not only the opponent, but also God. Among the indigenous Yine people Opas studies, morality in people's experiences of God is in a parallel and very physical way related to collective welfare. Given that other people as well as non-humans influence people's bodies and personhoods through physical interaction, and that living well and being a legitimate Christian ideally take place among people with similar (Christian) bodies, people's connections with transcendent actors, and thus the moral evaluations of people's dreams, gain enormous moral significance for the local Christian community. In Barnes's article the individual is placed at the centre of moral evaluation. He shows that moral and ethical struggles can arise from, and be targeted at, the believer's past. The subject of such evaluations is the self before and after the watershed of becoming a believer. In addition to the individual-collectivity axis the articles discuss moral evaluations in relation to discernment between God and the devil. As seen in the case of the Amazonian Yine evangelicals, interaction with the devil may have enduring effects on people's life and faith, which makes the act of discernment of great importance. In Haapalainen's article on Finnish Evangelical Lutherans this discernment concerns both the 'spirit world' and the 'false veneration of people'. The first focuses on the threat caused by the source of transcendent experiences potentially being Satan or demons rather than God; the second deals with the danger of individuals with spiritual gifts becoming objects of veneration instead of God. These problems are taken seriously in the Evangelical Lutheran parish, and the pastors instruct people in how they may be sure that the powers with which they are dealing are indeed from a divine source.

Finally, in relation to the analysis of Christian experiences of God's presence, Barnes and Opas raise the important question of the scholarly inability to take the Christian God seriously. While recent ontological, new materialist, and post-humanist attempts to rethink the position of the human subject and the subject-object relationship have made it possible to study deities in different religious and spiritual traditions not only as objects of human action but as subjects and actors in their own right (Espirito Santo \& Tassi 2013), it has proved difficult for religious scholarship to employ a 
similar approach to the Christian God (see Bialecki 2014). Unlike in many other cases it seems that taking the Christian God seriously amounts to the researcher subscribing to God's existence. This may in large measure result from the long tensional relationship between theology and social scientific research on Christianity (and especially the study of religion and anthropology). However, in the context of the current deliberate and explicit social scientific and humanistic project to find ways of taking the agency and subjectivity of various nonhuman - animate and inanimate - beings and substances seriously (e.g. Henare et al. 2007), the tide also seems to be turning here, enabling a fresh consideration of the problem of the Christian God. In discussing the influence of Christian transcendent others on believers the articles by Barnes and Opas, although approaching the question from different viewpoints, take a move toward bringing God and other Christian non-humans into the analysis as subjects.

Together, the papers in this special issue reveal the diverse ways in which the social other - whether human or other-than-human - influences the Christian experiences of being connected with God. In making this social connectedness visible this issue contributes to the development of the field of study of Christian and other religious experiences of the divine.

$* * *$

MINNA OPAS is Senior Research Fellow in Comparative Religion at the Turku Institute for Advanced Studies, University of Turku. Email: minna.opas@utu.fi

ANNA HAAPALAINEN is Doctoral Candidate in Comparative Religion at the University of Turku. Email: anna.haapalainen@utu.fi

Bibliography

\section{Bialecki, Jon}

2011 Quiet Deliverances. - Martin Lindhardt (ed.), Practicing the Faith: The Ritual Life of Pentecostal-Charismatic Christians, 249-76. New York \& Oxford: Berghahn.

2014 Does God Exist in Methodological Atheism? Tanya Luhrmann's 'When God Talks Back' and Bruno Latour. - Anthropology of Consciousness 25(1), 32-52.

2015 What is an Individual? The View from Christianity. - HAU: Journal of Ethnographic Theory 5(1), 271-94. 


\section{Bielo, James}

2004 Walking in the Spirit of Blood: Moral Identity among Born-Again Christians. - Ethnology 43(3), 271-89.

\section{Blackman, Lisa}

2012 Immaterial Bodies: Affect, Embodiment, Mediation. London: Sage.

Brahinsky, Josh

2012 Pentecostal Body Logics: Cultivating a Modern Sensorium. - Cultural Anthropology 27(2), 215-38.

\section{Bourdieu, Pierre}

1990 The Logic of Practice. Palo Alto: Stanford University Press.

Cassaniti, Julia L. \& Tanya Luhrmann

2011 Encountering the Supernatural: A Phenomenological Account of Mind. - Religion and Society 2, 37-53.

\section{Cattoi, Thomas \& June McDaniel}

2011 Perceiving the Divine through the Human Body. London \& New York: Palgrave Macmillan.

\section{Chidester, David}

2005 The American Touch. Tactile Imagery in American Religion and Politics. - Constance Classen (ed.), The Book of Touch, 49-65. Oxford: Berg Publishers.

\section{Classen, Constance}

1993 Worlds of Sense: Exploring the Senses in History and across Cultures. London: Routledge.

\section{Coleman, Simon}

2006 Materializing the Self: Words and Gifts in the Construction of Charismatic Protestant Identity. - Fenella Cannell (ed.), The Anthropology of Christianity, 163-184, Durham \& London: Duke University Press.

\section{Csordas, Thomas J.}

1993 Somatic Modes of Attention. - Cultural Anthropology 8(2), 135-56.

1994 The Sacred Self: A Cultural Phenomenology of Charismatic Healing. Berkeley: University of California Press.

2002 Body/Meaning/Healing. Contemporary Anthropology of Religion. Basingstoke: Palgrave Macmillan.

\section{de Witte, Marleen}

2009 Modes of Binding, Moments of Bonding. Mediating Divine Touch in Ghanaian Pentecostalism and Traditionalism. - Birget Meyer (ed.), Aesthetic Formations. Media, Religion and the Senses, 183-205. New York: Palgrave MacMillan.

2011 Touched by the Spirit: Converting the Senses in a Ghanaian Charismatic Church. - Ethnos 76(4), 489-509. 


\section{Douglas, Mary}

2002 [1966] Purity and Danger. London: Routledge.

\section{Espirito Santo, Diana \& Nico Tassi}

2013 Making Spirits: Materiality and Transcendence in Contemporary Religions. London \& New York: I. B. Tauris.

Gavrilyuk, Paul L. \& Sarah Coakley

2012 The Spiritual Senses: Perceiving God in Western Christianity. New York: Cambridge UP.

\section{Foucault, Michel}

1975 Discipline and Punish: the Birth of the Prison. New York: Random House. 1997 Technologies of the Self. In the Essential Works of Michel Foucault, 19541984. - Paul Rabinow (ed.); Robert Hurley et al. (trans.), vol 1: Ethics: Subjectivity and Truth, 223-52. New York: New Press.

\section{Hart, Kevin \& Barbara Wall}

2005 Experience of God: A Postmodern Response. New York: Fordham University Press.

\section{Henare, Amiria, Martin Holbraad \& Sari Wastell (eds)}

2007 Thinking through Things: Theorising Artefacts Ethnographically. London: Routledge.

\section{Hirschkind, Charles}

2006 The Ethical Soundscape. New York: Columbia University Press.

\section{Keane, Webb}

2007 Christian Moderns: Freedom and Fetish in the Mission Encounter. Berkeley: University of California Press.

\section{Klaver, Miranda \& Linda van de Kamp}

2011 Embodied Temporalities in Global Pentecostal Conversion. Special issue of Ethnos 2011(4).

\section{Lambeck, Michael}

2010 Ordinary Ethics: Anthropology, Language, and Action. New York: Fordham University Press.

\section{Latour, Bruno}

1993 [1991] We Have Never Been Modern. - Transl. Catherine Porter. Cambridge: Harvard University Press.

\section{Luhrmann, Tanya}

2004 Metakinesis: How God Becomes Intimate in Contemporary U.S. Christianity. - American Anthropologist 106(3), 518-28.

2012 When God Talks Back. Understanding the American Evangelical Relationship with God. New York: Vintage Books. 


\section{Mahmood, Saba}

2005 Politics of Piety: The Islamic Revival and the Feminist Subject. Princeton: Princeton University Press.

2014 Ethics and Piety. - Didier Fassin (ed.), A Companion to Moral Anthropology, 223-41. Hoboken: John Wiley \& Sons.

\section{Mauss, Marcel}

1973 Techniques of the Self. - Economy and Society 2(1), 70-88.

McGuire, Meredith B.

2016 Individual Sensory Experiences, Socialized Senses, and Everyday Lived Religion in Practice. - Social Compass 63(2), 152-62.

Merleau-Ponty, Maurice

1966 [1945] Phenomenology of Perception. London \& New York: Routledge.

\section{Meyer, Birgit}

2008 Religious Sensations: Why Media, Aesthetics, and Power Matter in the Study of Contemporary Religion. - Hent de Vries (ed.), Religion: Beyond a Concept, 704-23. New York: Fordham University Press.

2010 Aesthetics of Persuasion. Global Christianity and Pentecostalism's Sensational Forms. - South Atlantic Quarterly, 109(4), 741-63.

\section{Mitchell, Jon P.}

2015 Ontology, Mimesis, and Divine Intervention: Understanding Catholic Visionaries. - Michael Bull \& Jon Mitchell (eds), Ritual, Performance and the Senses, 11-30. London: Bloomsbury Publishing.

\section{Orsi, Robert A.}

2006 Between Heaven and Earth: The Religious Worlds People Make and the Scholars Who Study Them. Princeton: Princeton University Press.

\section{Rudy, Gordon}

2013 [2002] The Mystical Language of Sensation in the Later Middle Ages. New York: Routledge.

\section{Utriainen, Terhi}

2016 Doing Things with Angels: Agency, Alterity and Practices of Enchantment. - Riku Hämäläinen, Heikki Pesonen \& Terhi Utriainen (eds), Helsinki Study of Religions: A Reader, 138-51. Helsinki: Helsingin yliopisto.

\section{Weber, Max}

2005 [1930] The Protestant Ethic and the Spirit of Capitalism, Taylor and Francis e-Library edition. London \& New York: Routledge. 